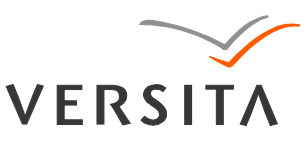

GEOCHRONOMETRIA 38(3) 2011: 282-291

DOI 10.2478/s13386-011-0041-6

Available online at

www.springerlink.com

\title{
POTENTIAL GEOARCHAEOLOGICAL SITES FOR LUMINESCENCE DATING IN THE GANGA BHAGIRATHI-HUGLI DELTA, WEST BENGAL, INDIA
}

\author{
SHARAD N. RAJAGURU ${ }^{1}$, BHASKAR C. DEOTARE ${ }^{1}$, KAUSHIK GANGOPADHYAY ${ }^{2}$, \\ MALAY K. SAIN ${ }^{3}$ and SHEENA PANJA ${ }^{3}$ \\ ${ }^{1}$ Department of Archaeology, Deccan College, Pune 411006 \\ ${ }^{2}$ Centre for Archaeological Studies \& Training Eastern India, Kolkata, 700016 \\ ${ }^{3}$ Dept. of AIHC and A, Visva Bharati, Santiniketan, 731235
}

Received 29 June 2010

Accepted 30 May 2011

\begin{abstract}
Archaeological studies in the upper and lower part of the Ganga-Bhaghrathi-Hugli delta were taken up to understand the nature of site formation and human adaptation in a dynamic fluvial zone. This aspect has been neglected in Indian archaeology. However archaeological dating using typological information, has an error margin of a couple of centuries and hence, is of limited use. We suggest that high resolution chronology using Optically Stimulated Luminescence (OSL) and radiocarbon dating can be quite effective in the study of archaeology and human environment relationship in the Ganga-Brahmaputra Delta (GBD).
\end{abstract}

Keywords: Alluvial archaeology, OSL dating, buried sites, delta.

\section{INTRODUCTION}

Recent research in earth sciences in the Bengal basin (covering west Bengal and Bangladesh) has enhanced our understanding of the evolutionary history of the GangaBrahmaputra delta (GBD) during the Late Quaternary (Umitsu, 1993; Goodbread and Kuehl, 1999; Stanley et al., 2000 and Allison et al., 2003). The main factors in the development of the GBD include tectonics, eustasy, climatic change and geomorphic processes that operate in the Ganga River on the West and the Brahmaputra River in the east.

Bandyopadhyay (2007) summarized the evolutionary history of the Bengal basin and indicated that the thickness of the sediments deposited during the Holocene varies from about $15 \mathrm{~m}$ over the Indian platform to $\sim 90 \mathrm{~m}$ in the deeper basin areas. It has been suggested that fol-

Corresponding author: S. Panja

e-mail: panja.sheena@gmail.com lowing an erosional phase, caused due to the Last Glacial Maximum (between 24-18 ka BP) low strand line, the delta started accreting between $11.5 \mathrm{ka}$ and $10 \mathrm{ka} \mathrm{BP}$, due both to a rapidly rising sea level and increased strength of summer monsoons. Marine transgression reached its present sea level around $5 \mathrm{ka}$ BP and then delta progradation rapidly started. The present morphology was achieved during the last $3.5 \mathrm{ka} \mathrm{BP}$. The settlement started around $2.5 \mathrm{ka} \mathrm{BP}$ in this region.

\section{Archaeological history}

Though the western upland areas of the Bengal basin had been occupied by prehistoric hunter gatherers since the Middle Pleistocene, evidence for food producing settled communities in the basin proper does not go beyond c. $4000 \mathrm{ka} \mathrm{BP}$. In the middle Bengal basin, rich cultural settlements since the Chalcolithic period have been found. In the early historic period (2.5 ka BP) settlements occur in parts of south, central and north Bengal 
and during the early medieval and medieval periods (1-1.5 ka BP onwards) the entire basin was populated (Fig. 1, Table 1).

So far the chronology is largely based on archaeological information such as stylistic dating, comparative analysis of artifacts like pottery, terracotta figures, sculptures dated elsewhere and other objects and information obtained from coins and epigraphic sources.

\section{Alluvial archaeology}

Fluvial regimes in deltaic setting are known for frequently changing erosional and depositional locations caused due to changing hydrological and sedimentation pattern. In view of this, the archaeological records preserved in alluvial settings are dramatically affected by temporal changes in fluvial processes. Moreover cultural adaptation also depends on the nature of the fluvial terrain.

Till date, archaeological research in India has concentrated on "mound" archaeology whereby huge imposing mounds like those in the middle Ganga plains in North India or the dry regions of western and central India have been the focus of research. Compared to this, archaeological sites in a dynamic alluvial setting have so far been neglected as they have been classified as "disturbed" and thus not important for archaeological research. However work in other parts of the world have shown that archaeological sites in dynamic alluvial settings are indeed a very important indicator of human adaptation and site formation and preservation in these regions is different from other types of environments. Multidisciplinary work in similar aspects in other parts of the world such as e.g. the Thames valley in England, the Nile valley in Egypt, Mississippi valley and other areas in the USA (like the Colby site in Wyoming and the Coffey site in Kansas as well as the Hohokam settlements) and China have been reported. The studies fall into two categories. The first includes locational studies which are mostly concerned with identifying the character of the alluvial system which seem to provide some explanation on site location and site preservation. The other involves the understanding the geomorphological context of the site, an understanding of which informs on both the context of preservation of the site, as well as the original landscape where the human settlements began in this region (Brown, 1997; Waters, 1993).

River Ganga, as we know has the tendency to shift the courses through time and former courses are left behind as moribund channels (Rudra, 2009). Many of the archaeological sites are found along these moribund (almost dead or inactive) channels. Consequently, the understanding of the palaeofluvial landscape is an important aspect in geoarchaeological research in this area along with site formation, cultural adaptation and for future global change studies.

In absence of absolute dating, it is difficult to ascertain the spatial and temporal evolution of the human settlements in the GBD. In the fluvial system sediment organic carbon relationship remains suspect hence the applicability of the conventional radiocarbon chronology has limited use, which is not the case with OSL dating that dates the most recent burial of sediments. We thus feel that the OSL chronology in the GBD can help in understanding the nature of human adaptation in dynamic delta environment and the interrelationship between natural fluvial and estuarine processes, and the archaeological record preserved in low energy sediments. Such an archaeological work can also add a further dimension to understanding alluvial environments and cultural signatures which often complements or enhances information from other sciences.

It is in this regard that we present the analyses of three archaeological sites in different parts of the GBD in West Bengal, India (Fig. 1, Table 2)

\section{ARCHAEOLOGICAL CASE STUDIES}

\section{Balupur}

The buried site of Balupur is located in the acutely meandering loops of the river Kalindri in the northern part of the GBD (Fig. 2) on an alluvial fill surface 6-7 m above the modern channel of the Kalindri which is about $18 \mathrm{~m}$ asl and was occupied between the $5^{\text {th }}-19^{\text {th }}$ century $\mathrm{AD}^{1}$.

The floodplain fill is a part of the Ganga-Mahananda riverine segment. Analysis of old maps, aerial photographs and satellite imageries of the site and the region have shown that the Kalindri changed its course frequently, the present bed being in places at some distance from the position of the river. In order to understand in greater detail the nature of the palaeofluvial system and the link between fluvial dynamics and human adaptation, excavations were undertaken on the habitation site.

The site was divided in 5 Sectors, and and 36 trenches were excavated to a depth varying from $3 \mathrm{~m}$ to $7 \mathrm{~m}$. These trenches reveal a complex relationship between archaeological / cultural layers and natural flood deposits which occur as lenses within cultural layers. We have selected one trench (TT33) which has preserved most of the cultural phases within a depth of $5.3 \mathrm{~m}$. In the following paragraphs we have briefly described the geoarchaeology and chronology of the cultural layers and associated flood deposits (Figs. 3-4).

The basal virgin layer devoid of cultural material, is exposed a few metres away from T33 at a depth of 5.5 to $6.0 \mathrm{~m}$ below the surface and about 1.5 to $2.0 \mathrm{~m}$ above the present channel of the Kalindri. The virgin layer is a brownish compact silty clay (about $35 \mathrm{~cm}$ thick) with a development of blocky pedal structures. Presence of black mottles and pellets of iron-manganese oxides,

\footnotetext{
1 The excavations at Balupur were conducted by the Department of Ancient History and Archaeology, Visva Bharati, Santiniketan under the direction of Arun K. Nag and Sheena Panja between 2005 and 2008.
} 


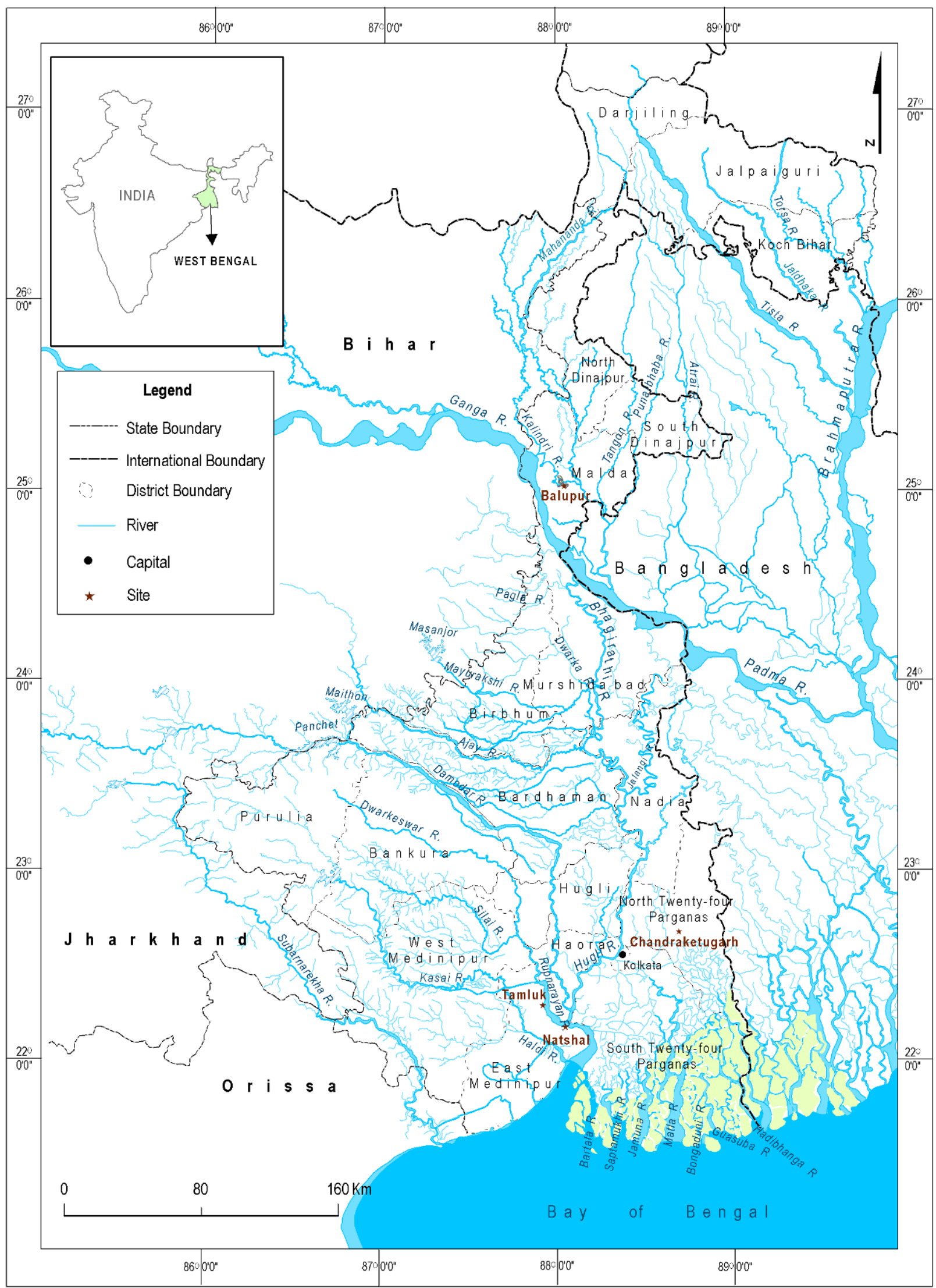

Fig. 1. Map of sites 
calcrete pellets and nodules ( $2 \mathrm{~cm}$ along long axis) indicates that the virgin layer has undergone pedogenesis under hydromorphic conditions. This represents a stable floodplain surface over which the first human settlement took place. The nature of potsherds and their affinity with the dated potsherds sites in North India suggest a tentative dating of the earliest cultural phase of 5-7th C AD.

The cultural layer is capped by a flood deposit grayish yellow, $60 \mathrm{~cm}$ thick with weakly laminated layers of silt and fine sand (Flood I). The flood deposit has undergone moderate pedogenesis, as indicated by the presence of calcrete nodules and rhizoconcretions. This deposit is almost free from archaeological antiquities and has been OSL dated to $1.2 \pm 0.2 \mathrm{ka}(825 \mathrm{AD})$ at the Wadia Insitute of Himalayan Geology, Dehradun, India (Table 3).
The stabilized surface of flood deposit is capped by a $60-80 \mathrm{~cm}$ thick cultural layer, with excellent preservation of mud floors, hearth, lumps of charcoal, a few intact earthen pots and good number of animal bones in a matrix of yellowish brown sandy silt. Based on the archaeological antiquities, this layer corresponds to the early medieval period (ca. $7^{\text {th }}$ to $9^{\text {th }}$ century AD). Presence of $40 \mathrm{~cm}$ thick light brown loam with a few antiquities indicates that the settlement was affected by a low energy flood, sometime in early $10^{\text {th }}$ century AD (Flood II). The flood loam is weakly pedogenised as indicated by the development of crumb and blocky structures and by the presence of blackish iron-manganese mottles and pellets.

The stable pedogenised surface of flood deposits is covered by a light brown sandy silty cultural layer with good preservation of mud floors, rammed floors, pottery,

Table 1. Archaeological phases in the GBD Delta

\begin{tabular}{|c|c|c|c|}
\hline Cultural Periods & Dates & Methods of Dating & Regions \\
\hline Early Historic & $\begin{array}{l}3^{\text {rd }} \text { century B.C. - } \\
3^{\text {rd }} \text { century A.D }\end{array}$ & $\begin{array}{l}\text { Pottery, terracotta figurines and plaques, beads, architectural } \\
\text { ceramics like perforated tiles, coins. }\end{array}$ & $\begin{array}{l}\text { Mostly south and } \\
\text { central GBD }\end{array}$ \\
\hline Historic / Late Historic & $4^{\text {th }}$ century A.D & Coins, stone plaques, terracotta figurines, & $\begin{array}{l}\text { Mostly south and } \\
\text { central GBD }\end{array}$ \\
\hline Early Medieval" & 8-12 $2^{\text {th }}$ century $A D$ & $\begin{array}{l}\text { Diagnostic pottery mostly from monastic sites, Brick sizes } \\
\text { Epigraphic evidence, Scupltures } \\
\text { AMS radiocarbon dates from Balupur, Mahasthan, Bangladesh }\end{array}$ & Entire GBD delta \\
\hline $\begin{array}{l}\text { Medieval (sometimes } \\
\text { called Sultunate) }\end{array}$ & $13^{3^{\text {th}}}-15^{\text {th }}$ century $A D$ & $\begin{array}{l}\text { Coins, epigraphic, literary evidence, limited diagnostic pottery } \\
\text { from large towns like Gaur in the north part of the Delta } \\
\text { Brick size }\end{array}$ & Entire GBD delta \\
\hline $\begin{array}{l}\text { Late Medieval (sometimes } \\
\text { called Mughal) }\end{array}$ & $16^{\text {th }}-18^{\text {th }}$ century $A D$ & $\begin{array}{l}\text { Literary, coins, inscriptions and some diagnostic pottery mostly } \\
\text { compared to other parts of India } \\
\text { Brick size }\end{array}$ & Entire GBD delta \\
\hline
\end{tabular}

"Work on establishing a pottery sequence from the early to late medieval periods is on progress at the site of Balupur results of which are awaited

Table 2. Context of sites

\begin{tabular}{|c|c|c|c|}
\hline S. No. & Site & $\begin{array}{l}\text { Approximate Age } \\
\text { (based on archaeological data) }\end{array}$ & Geomorphic context \\
\hline 1 & $\begin{array}{l}\text { Balupur } \\
\text { Dist. Malda, about } 370 \mathrm{~km} \text { north of Kolkata }\end{array}$ & $\begin{array}{l}\text { Primarily Medieval } \\
(\sim 1.5 \text { ka BP onward })\end{array}$ & $\begin{array}{l}\text { Upper Ganga delta } \\
\text { Dominated by alluvial flood plains, } \\
25 \mathrm{~m} \text { ASL }\end{array}$ \\
\hline 2 & $\begin{array}{l}\text { Chandraketugarh Dist. North } 24 \text { Parganas, about } 38 \\
\text { km NE of Kolkata }\end{array}$ & $\begin{array}{l}\text { Primarily Early Historic } \\
(\sim 2.5 \text { ka BP onward })\end{array}$ & $\begin{array}{l}\text { Middle Ganga delta } \\
\text { Interface of fluvial and tidal flood plains, } \\
10-15 \mathrm{~m} \mathrm{ASL}\end{array}$ \\
\hline 3 & Natsal, Dist. Midnapur, about $100 \mathrm{~km}$ west of Kolkata & $\begin{array}{l}\text { Primarily Early Historic } \\
\text { ( } 2.5 \text { ka BP onward) }\end{array}$ & $\begin{array}{l}\text { Lower Ganga delta } \\
\text { Estarine flood plains, } \\
\text { less than } 10 \mathrm{~m} \mathrm{ASL}\end{array}$ \\
\hline
\end{tabular}

Table 3. OSL date of sediment from Balupur site

\begin{tabular}{lcccccccc}
\hline Lab No. & Sample no. & $\begin{array}{c}\mathrm{U} \\
(\mathrm{ppm})\end{array}$ & $\begin{array}{c}\text { Th } \\
(\mathbf{p p m})\end{array}$ & $\begin{array}{c}\mathrm{K} \\
(\%)\end{array}$ & $\begin{array}{c}\text { Moisture } \\
\text { Content } \\
(\%)\end{array}$ & $\begin{array}{c}\text { Equivalent dose } \\
(\mathrm{Gy})\end{array}$ & $\begin{array}{c}\text { Dose rate } \\
(\text { Gy/ka) }\end{array}$ & $\begin{array}{c}\text { Age } \\
(\mathrm{a})\end{array}$ \\
\hline LD439 & BLP-1 & $2.10 \pm 0.02$ & $15.80 \pm 0.16$ & $2.32 \pm 0.02$ & 1.13 & $4.79 \pm 0.72$ & $4.06 \pm 0.06$ & $1180 \pm 180$ \\
\hline
\end{tabular}

Mineral used: Quartz, Grain Size: 90-125 $\mu$ m; OSL analysis protocol: Single Aliquot Regeneration (SAR) protocol (Murray and Wintle, 2000) 


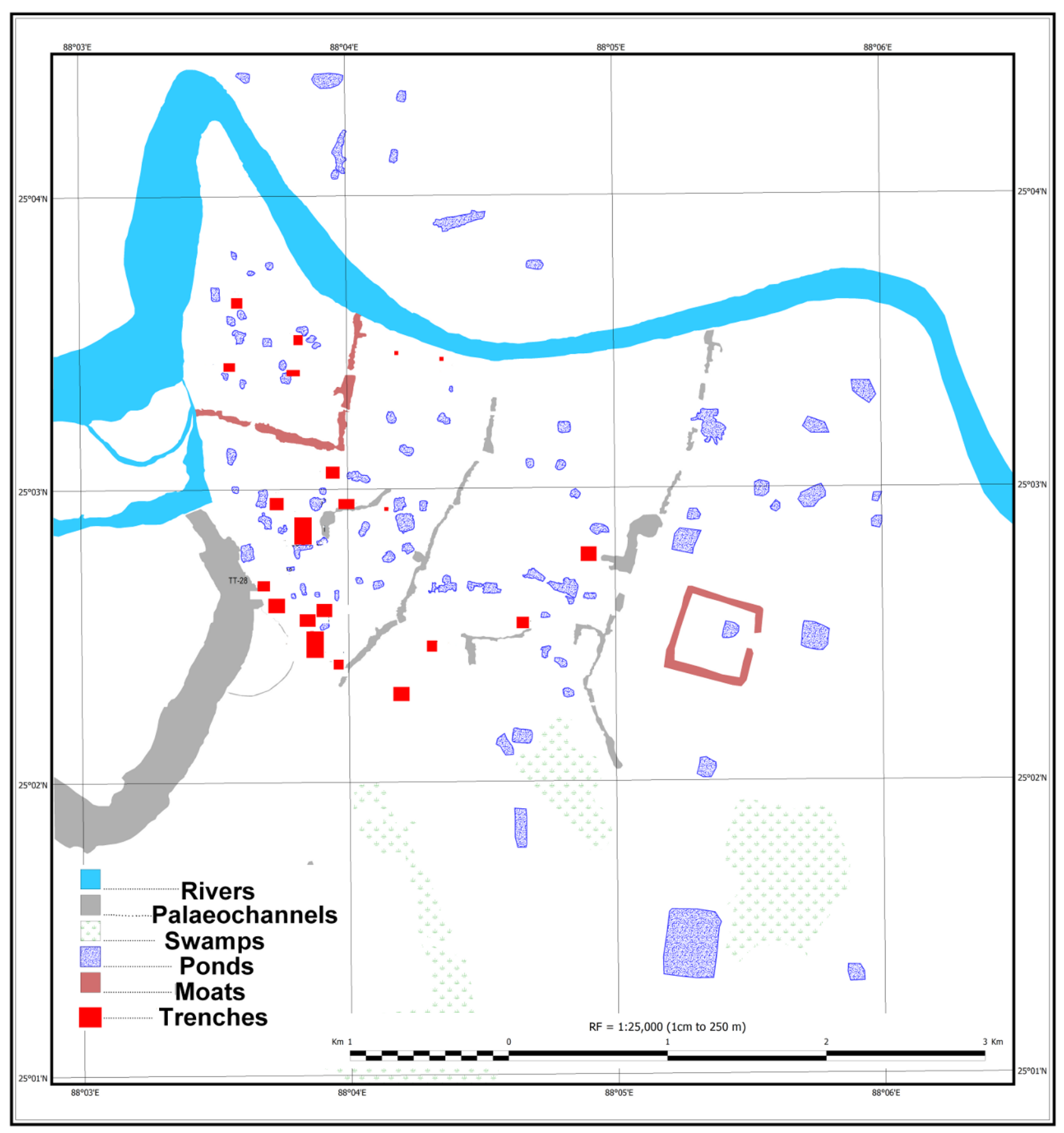

Fig. 2. The site of Balupur

bone working spots and a few intact earthen pots. This cultural layer about $60 \mathrm{~cm}$ thick, is dated to $10^{\text {th }}-11^{\text {th }}$ century $\mathrm{AD}$ on the basis of archaeological antiquities including a seal palaeographically dated to the $10-11^{\text {th }}$ century AD. This was also affected by a low energy flood probably in early $12^{\text {th }}$ century AD (Flood III). The flood deposit is about $30-40 \mathrm{~cm}$ thick, loamy in texture and with a few antiquities.
A period between $13^{\text {th }}$ century $\mathrm{AD}$ and $15^{\text {th }}$ century $\mathrm{AD}$ was culturally rich without any significant disturbance by flood. This cultural phase is represented by $40-50 \mathrm{~cm}$ thick light brown sandy silt layer with excellent preservation of rammed floors, large brick structures, fine textured pottery and antiquities of advanced craftsmanship. This phase continued in $16^{\text {th }}$ century AD with evidence of copper and iron smelting, bead making, stone 


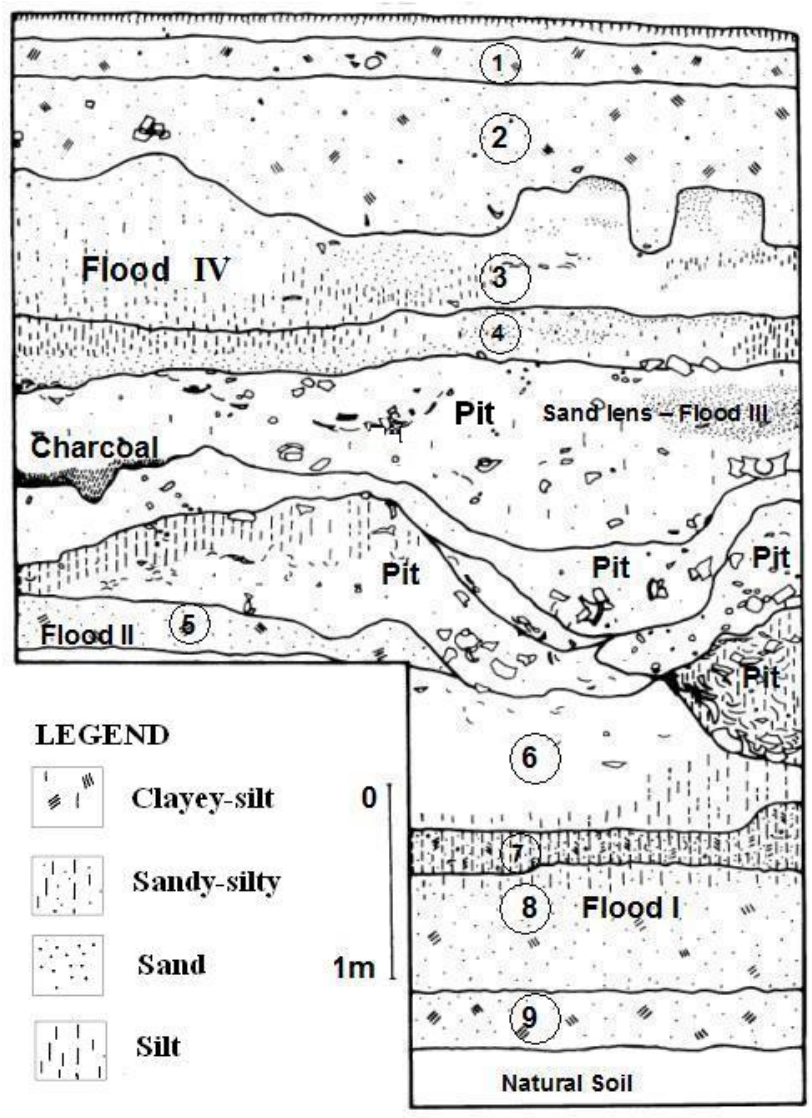

Fig. 3. Stratigraphy of TT33

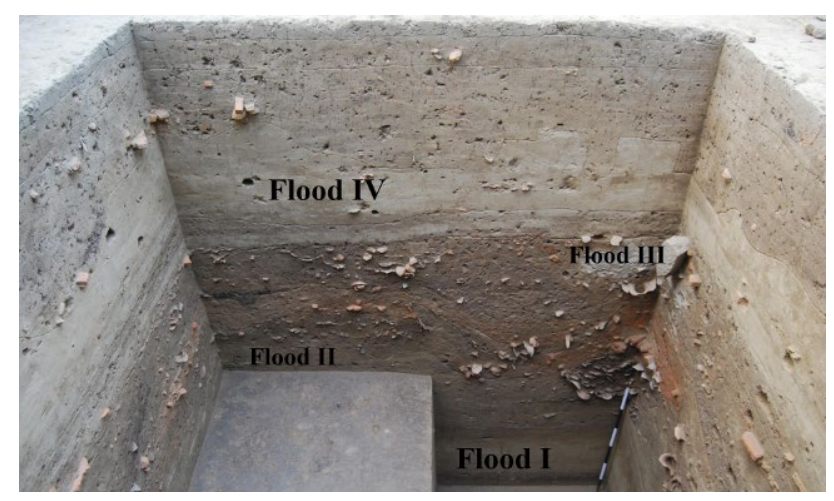

Fig. 4. Section TT33

working and, production and exchange of glazed, celadon and porcelain pottery.

At the beginning of $16^{\text {th }}$ century $\mathrm{AD}$, the settlement was affected by a flood as indicated by the presence of $65 \mathrm{~cm}$ thick yellowish brown silty sand occurring $30 \mathrm{~cm}$ below the surface (Flood IV). This flood occurred when the site was occupied by people using glazed pottery and beads. Human skeletal remains and brick structures were found in this layer. Typotechnology of ceramics from similar sites in North India, suggest that this cultural phase can be tentatively dated to $15-16^{\text {th }}$ century AD.

The terminal cultural phase is represented by cultural layers surface to $35 \mathrm{~cm}$. Late medieval phase continued and was followed by the cultures of the last 300 years which is termed as the colonial culture. The culture of both these phases have evidence of flimsy structures made with reused or broken bricks. In this phase we also get evidence of human remains. There is some evidence of craft/industrial activity like stone working, pottery, bead making, copper casting. The terminal cultural phase was not affected by floods, but by surface flow of water during rainy season. The habitation was disturbed by colluvial processes as indicated by the presence of lenticular concentration of broken potsherds and stone chips.

Our observations in T33 show that four (Figs. 3-4) floods have affected the settlement of Balupur in a period of about 800 years. These floods were of a low energy overbank type and are labelled as "nuisance floods" (Brown, 1997). This could mean that the site was not situated on the main bank of the Ganga but probably a distributary like the contemporary Kalindri. However unlike the modern river which is almost a defunct stream the river must have been mightier and prone to periodic but low energy floods. It is also observed that these floods occurred once in a century and their frequency reduced after $12^{\text {th }}$ century and nearly no flooding occurred in the terminal phase of the settlement in $17^{\text {th }}$ to $19^{\text {th }}$ century AD.

Texturally, the flood deposits and cultural layers are loamy (with almost equal proportion of sand, silt and clay), light brown to yellowish brown in colour, moderately alkaline with $\mathrm{pH}$ varying from 7 to 8 , low in organic carbon $(<0.2 \%)$ and phosphorus content varying from 0.03 to $0.23 \%$. Low phosphorus content and relatively poor preservation of antiquities confirm the field identification of flood deposits. Mineral composition of fine sand fraction of flood deposits, of palaeochannel and of modern levee banks of Kalindri and the Ganga shows dominance of quartz, feldspar and moderate amount of muscovite and biotite. Minerals like sillimanite, zircon and apatite occur in traces.

Balupur is an interesting example of site formation in flood zone of the upper Ganga delta. It has been seen that undisturbed archaeological sites are likely to occur in the vertical accretion sediments of the floodplain in meandering rivers (upper point bars, crevasse splays, oxbow lakes and flood basins). Occupation usually takes place on the lowlands adjacent to an active river channel during a period of stability. This has probably happened at $\mathrm{Ba}-$ lupur, after the site was abandoned because of inundation by flood. Following each period of stability and occupation, floodwaters inundated and covered the surface. The systemic context of each occupation surface was virtually undisturbed by over bank flooding and burial. Because sedimentation was fairly regular and rapid, the assemblages represent temporally discrete entities. Archaeolog- 
ical data like brick structures rammed floors, charcoal and ash layers intact pots, unweathered potsherds of different dimensions and preservation of fragile animal and human bones indicate occurrence of primary to semi-primary material in low energy short lived flood deposits, laid down by a seasonally flowing meandering river with few episodes of short-lived high intensity floods. It is a unique example of human adaptation to a meandering dynamic fluvial system.

Based on the geoarcheology, sedimentology, geomorphology and limited chronology following inferences can be drawn.

1) The first settlement of $5-7^{\text {th }}$ century $\mathrm{AD}$ has taken place on a stable floodplain of a stream which was flowing couple of meters below the present channel level. This settlement was affected by low energy overbank flood sometime during $9^{\text {th }}$ century $\mathrm{AD}$. This flood might have occurred in response to crevasse splay processes or to avulsion of the channel.

2) The flood loam was affected by pedogenesis as indicated by the occurrence of calcrete nodules, rhizoliths and pellets in this deposit.

3) After the flood of $9^{\text {th }}$ century AD, the human activity continued till $16^{\text {th }}$ century $\mathrm{AD}$ without any major disturbance by strong floods. Two nuisance floods during the intervening period of 700 years, occurred. The stream was probably in an aggradational mode, and thus flooded the settlement temporarily without affecting habitational structures, including the hearths.

4) The site was marginally affected by a flood sometimes in $16^{\text {th }}$ century AD. Primary human activity continued without being adversely affected by this flood. This is indicated by preservation of human skeletons in layers associated with flood loams.

5) Human activity continued for another 300 years in culturally degraded forms. During this period, the stream changed to an incisional mode and reached its present level sometime in the beginning of last century.

In such a terrain, archaeological work has to be combined with OSL and other forms of dating like AMS to understand the evolution of the palaeofluvial systems as well as the nature and change of human cultural adaptation.

\section{Chandraketugarh}

Another area of potential OSL dating is in the southern part of the Delta situated between two major distributaries of the Ganga, the Bhagirathi-Hughli to the west and Mathabhanga-Ichamati (known as Padma in Bangladesh) to the east. Both distributaries flow into Bay of Bengal. Chandraketugarh is a buried site with only a few structural remains partly visible on the ground. Surrounding upper delta plain shows palaeo-channels, -levees, - point bars and ponds, etc. It has not yet been possible to date these ancient features with archaeological remains. These occur some 2 to $2.5 \mathrm{~m}$ below the alluvium from the surface. Recently Chakrabarti et al. (2007) attempted to resolve this problem by preparing a detailed geomorphological map and also by analysing three undisturbed sediment cores to depths of $10 \mathrm{~m}$ in alluvial plain surface surrounding the site. Geomorphology of meander belts developing in upper delta produce distinctive crosscutting relationship of meander belts. The older belt is cut by younger meander belt. It was for the first time that the evolutionary history of the Ganga and its distributaries was reconstructed on the basis of cross-cutting relationship of various meander belts. In all 5 meander belts were mapped. It was shown that the earliest settlement $(\sim 2.5 \mathrm{ka} \mathrm{BP})$ occurred on a broad and high levee of welldeveloped meandering distributary carrying considerable discharge connected to the Bay of Bengal through distributaries developed in adjacent tidal plain. Chandraketugarh flourished as an inland port on a distributary of the Ganga. The settlement declined after several centuries due to a change in landscape, as shown by the younger meander belts. It has been argued that the old distributary lost its connection with the Bay of Bengal due to changes in the meandering courses.

A hypothesis of growth and decay of an important site of Early Historic period has been developed on the basis of geomorphic studies of meandering belts and, this needs testing using absolute dates of sediment samples of cores. A single AMS date at a depth of about $3.6 \mathrm{~m}$ is 3,412 \pm 136 BP. This date does not accord with potsherds of Early Historic period found at that depth and implies that AMS radiocarbon dates is perhaps erroneous on account of contamination. Archaeological work combined with dating can better inform on the palaeofluvial system and human interaction in this region (Chakrabarti et al., 2007).

\section{Natsal}

Natsal is another buried historical site in the estuary of River Rupnarayan on a tidally influenced (with a tidal range of $5 \mathrm{~m}$ ) alluvial flat of the Lower delta. The site occurs $5 \mathrm{~m}$ above sea level and is approximately $30 \mathrm{~km}$ from the coast. It is a satellite settlement of Tamluk identified with the ancient port of Tamralipti (Ramachandran, 1951) situated $18 \mathrm{~km}$ upstream. Tamluk is also a buried site. Excavation by the Archaeological Survey of India (IAR 1954-55: 19 and IAR 1973-74: 33) revealed four cultural phases (Chalcolithic to Early Historic). Subsequent medieval period was found in rather disturbed condition. Natsal was excavated by the West Bengal's State Department of Archaeology, during 1999-2000. The excavators identified Chalcolithic (Black and Red ware pottery), early historic and medieval (approximately $3 \mathrm{ka}$ BP) phases. Their findings included pottery, few beads and a large number of bones and also bone tools.

Though the 'site' has been mentioned by a numerous archaeologists (Sengupta, 1995; Datta, 2000), no attempt has as yet been made to understand the formation process 
of this site. It will be apposite to mention that several other 'sites' in the Bengal delta have been found in similar context, however, the formation processes of these sites have never been probed by archaeologists who were more interested in studying the antiquities from the sites. The present location of the 'sites' (below the high tide level) holds important clues to the changing landscape of the Rupnarayan estuary during the late Holocene period.

We therefore re-examined the site for a better understanding of the cultural and the environmental context during the historical period, covering the last 2000 years. We argue that taphonomic study of both artefacts and ecofacts, can help develop a cogent argument on the formation processes of the sites.

The Rupnarayan estuary is a sub-system of the Hugli estuarine complex. It occupies a sand-silt- clay dominated morphostratigraphic unit termed as Panskura formation of varied depth from 1 to $15 \mathrm{~m}$ and radiocarbon dated to between $5 \mathrm{ka} \mathrm{BP}$ and $0.7 \mathrm{ka} \mathrm{BP}$. Archaeological explorations have revealed sites from $3 \mathrm{ka}-2.5 \mathrm{ka} \mathrm{BP}$ to $0.5 \mathrm{ka}$ BP. It is situated on the north-eastern boundary of Medinipur district and debouches into the Hugli at Hugli point. The river has a length of $\sim 60 \mathrm{~km}$ while the estuarine section of the River has a length of thirty $\mathrm{km}$. It widens considerably at the mouth having at places a breadth of nearly $4.5 \mathrm{~km}$ (Fig. 5).

Table 4 describes the sedimentary succession at Natsal, which was scraped to ascertain the context of the rolled as well as unrolled pottery. The section was exposed as a result of erosion by the Rupnarayan (Figs. 6-7).

Table 4 shows that sediments containing archaeological antiquities are weakly pedogenised in upper part $(0-40 \mathrm{~m})$ and are bioturbated in lower part. A concretion of rolled early historic and medieval at a depth of $1.43 \mathrm{~m}$ suggests reworking of pottery through surface sheet water accumulated during the rainy periods. Such surface processes were responsible for lateral concentration of pottery and was observed at Balupur. Clay pellets, occurring in silty clay between, indicate that they have formed in fluctuating saline-fresh water hydrological environment. Clay pellets, such as these, have been observed in lunette clay dunes bordering saline lakes in Australia where lake hydrology has fluctuated during the late Pleistocene (26 ka-18 ka BP; Bowler and Thorne, 1976). We have also found clay pellets in channels ridges formed during the mid late Holocene high sea level phase on the Gulf of Kutchchh in northern Saurashtra, N W Gujarat.

Besides clay pellets, a few well developed ferruginous rhizoconcretions (5 $\mathrm{cm}$ in length) were found at a depth of $1.30 \mathrm{~m}$. These rhizoconcretions though found in a secondary context, indicate the presence of a stable land

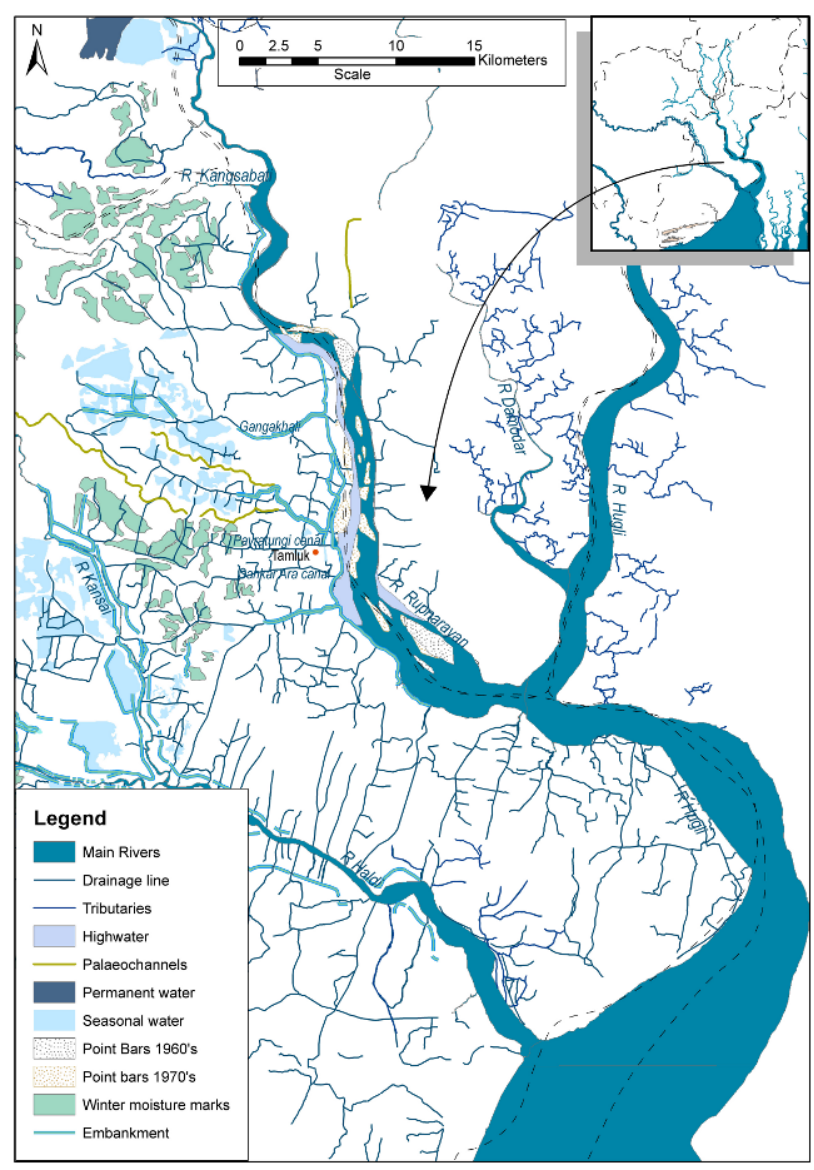

Fig. 5. Rupnarayan estuary

Table 4. Stratigraphy of Natsal

\begin{tabular}{rlll}
\hline Depth $(\mathbf{m})$ & Lithological Unit & Artefacts & Approximate Age \\
\hline $0-10$ & $\begin{array}{l}\text { Yellowish brown silty sand } \\
\text { weakly pedogenised }\end{array}$ & A few intact pots along with unrolled potsherds & Medieval \\
\hline $1.10-1.30$ & $\begin{array}{l}\text { Yellowish silty sand } \\
1.30-1.40\end{array}$ & $\begin{array}{l}\text { B few rolled potsherds along with a good number of unrolled } \\
\text { potsherds }\end{array}$ & Medieval \\
\hline $1.40-1.50$ & $\begin{array}{l}\text { Yellowish grey silty clay } \\
\text { with clay pellets }\end{array}$ & Potsherds rolled and fragmented, charcoal, animal bones & Early historic \\
\hline $1.50-1.70$ & $\begin{array}{l}\text { Light grey silty clay with } \\
\text { clay pellets }\end{array}$ & $\begin{array}{l}\text { A few intact pots along with unrolled potsherds, animal bones } \\
\text { and charcoal }\end{array}$ & Early Historic \\
\hline $1.70-1.85$ & $\begin{array}{l}\text { Light brownish silty clay } \\
\text { with clay pellets }\end{array}$ & $\begin{array}{l}\text { Good number of intact pots, with unrolled potsherds, animal } \\
\text { bones, charcoal, few potsherds of the Black and Red ware type }\end{array}$ & $\begin{array}{l}\text { Early historic with suspec- } \\
\text { ted Chalcolithic. }\end{array}$ \\
\hline
\end{tabular}




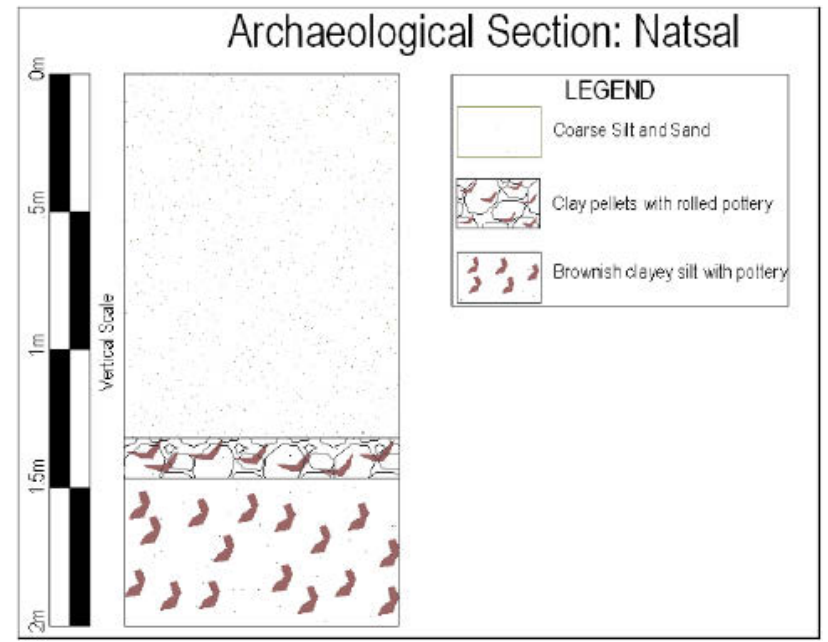

Fig. 6. Archaeological section: Natsal

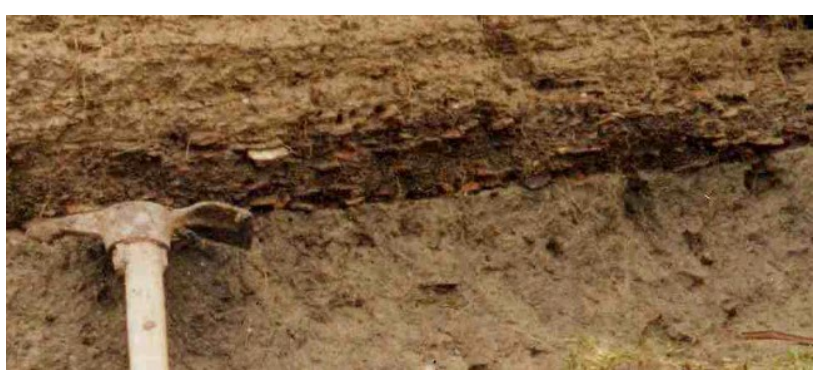

Fig. 7. Exposed section at Natsal

surface not far away from the present exposed bank section of the Rupnarayan. The buried palaeoland surface can be understood after considering sedimentological and palynological data preserved in cores taken at Kolaghat (Hait et al., 1996), a place situated $18 \mathrm{~km}$ upstream of Tamluk.

The borehole data from Kolaghat shows that peat developed around 6.9 ka BP (based on AMS date) which today occurs $2 \mathrm{~m}$ below the present sea level. The overlying $7 \mathrm{~m}$ thick sediments are non-marine alluvial origin and suggest progradation of delta after $6.9 \mathrm{ka}$ BP. Archaeological evidence at Tamluk shows that the Chalcolithic habitation took place on a stable tidal flat $+3 \mathrm{~m}$ above the present sea level around $3 \mathrm{ka} \mathrm{BP}$. Evidence at Kolaghat indicates subsidence after 6.9 ka BP and geoarchaeological data at Tamluk shows emergence sometimes before $3 \mathrm{ka} \mathrm{BP}$. Future geoarchaeological work at Tamluk and Natsal with good number of absolute dates will provide new information on delta evolution in the Rupnarayan Hugli estuary.

Table 4 shows that a $20 \mathrm{~cm}$ thick lens lies between $1.30-1.50 \mathrm{~m}$ containing fragmented potsherds, of $4 \mathrm{~cm}$ to $1 \mathrm{~cm}$ size. The lens overlies stiffer mud containing intact pottery pieces, which can be relatively dated to the early historic period as the rims along with the original fabric and treatment of the pots, have been preserved. To understand this apparent paradox we followed a modified method proposed by Allen for estimating roundness of transposed ceramic sherds in the Severn estuary (Allen, 1989). We analyzed nearly eight hundred sherds ranging from $1 \mathrm{~cm}$ to $4 \mathrm{~cm}$ in size. Roundness was measured using the waddle scale and based on roundness chart for pebbles used by Krumbein (Krumbein, 1941). It will suffice here to state that roundness decreases from 1 to 0.1 . A perfect ball has a roundness value of 1 . Silhouette of each sherd was thereby given a score between .9 and .1 after placing them on a flat slide viewer and comparing with Krumbein's chart (Gangopadhyay, 2006).

The conclusions reached here was that the sherds are mostly sub-rounded or sub-angular rather than being rounded or angular. Also, sherds with higher roundness value $(0.5)$ are present more at the top of the lens at $1.41 \mathrm{~m}$ while at the bottom of the lens at $1.51 \mathrm{~m}$ sherds had a lesser roundness value ( 0.2 to 0.3 ) and tended towards more angularity. This difference was also checked through the $t$-test. This probably reflects that they have been disturbed through fluvial action but not transported over a long distance. The disturbance is probably local caused by repeated exposure and burial of the site. This is also supported by faunal analysis. His observation is that the source of the faunal materials was probably in close proximity as indicated by the absence of severe to moderate abrasion, (V. Sathe, Deccan College, Pune: pers. comm.).

By using a relatively new methodology of studying degree of rolling of potsherds, we have been able to show that even though Natsal is in a secondary context, its primary provenance is on stable tidal flat surface not far away from the secondary site. A site like Natsal therefore provides a great opportunity through a combination of dating and archaeological work in order to understand the palaeolandscape and human adaptation in a tidal zone.

\section{CONCLUSIONS}

This is the first attempt at understanding 'cultureecology' of the GBD during the late Holocene $<3 \mathrm{ka}$ BP by meticulously collecting archaeological data in the context of alluvial sediments preserved in the delta. Out of three sites, Chandraketugarh is a buried site while Balupur and Natsal are partially buried sites. Balupur in the Upper delta of the Ganga, shows that human activity continued without any major break for about 1200 years in a sheltered geomorphic niche of the non-tidal meandering Ganga. It is also observed that only 4 nuisance floods occurred during that period with a reduced frequency of floods after the $12^{\text {th }}$ century AD.

Natsal and Tamluk flourished as estuarine creek ports in the Rupnarayan-Hugli delta almost since $3 \mathrm{ka} \mathrm{BP}$ and human activity took place on a stable yet rolling surface (+ $3 \mathrm{~m}$ asl) developed on tidally affected estuarine sediments. It appears that the Rupnarayan-Hugli tidal chan- 
nels were slightly entrenched and stable during the Late Holecene in the lower delta.

These findings however, lack precise chronological control. Archaeological dating, with a margin of couple of hundred years, is useful only in a limited way. It is therefore necessary to have high resolution chronological data generated by ${ }^{14} \mathrm{C}$, AMS and luminescence dating (both TL and OSL). A few AMS dates obtained for a sedimentary core taken near the site Chandraketugarh do not accord with archaeological dates. In view of certain limitations of conventional C-14 and AMS dates in delta sediments (Stanley et al., 2000).

We suggest that the OSL dating might be used for primary or semi-primary archaeological sites which are present in large number in the GBD. Singh et al. (1998) have already shown the potential of luminescence dating of delta sediments particularly silts and sands and recent developments in OSL dating may provide valuable insights.

Such high resolution investigations of archaeological sites preserved in the GBH can also provide insight into meandering process in non-tidal part of the upper delta and into the estuarine processes in the tidal part of the lower delta. The most important contribution of future multi-disciplinary studies will be for understanding man induced changes in the landscape during the Late Holocene. Recently Tony et al. (2009) carried out multidisciplinary studies in Rhone delta in South France and have provided new information on man-induced changes in the delta environment. These changes are related to salinization of cultivated lands, decline of bio-diversity of wetlands and tide-induced erosion in estuaries. We suggest that similar studies may be undertaken at promising archaeological sites in the GBHD in future.

\section{ACKNOWLEDGEMENTS}

The first three authors are grateful to the Centre for Archaeological Studies and Training, Eastern India. We wish thank Sutapa Roy for the preparation of some of the maps in this paper and Deccan College, Pune for their support and help. The authors wish to thank the anonymous reviewers whose comments helped us to reform and finalize the text.

\section{REFERENCES}

Allen JRL, 1989. A Quantitative Technique for Assessing the Roundness of Pottery Sherds in Water Currents, in Geoarchaeology 4(2): 143-155, DOI 10.1002/gea.3340040204.

Allison MA, Khan SR, Goodbred SL Jr. and Kuehl SL, 2003. Stratigrpahic evolution of the late Holocene Ganges Brahmaputra lower delta plain. Sedimentary Geology 155(3-4): 317-342, DOI 10.1016/S0037-0738(02)00185-9.

Bandyopadhyay S, 2007. Evolution of the Ganga - Brahmaputra Delta : A Review. Geographical Review of India 69(3): 235-268.

Bowler JM and Thorne AG, 1976. Human remains from lake Mungo. In: Kirk RL and Thorne AG, eds. Origin of the Australians. Australian Institute of Aboriginal studies publications, Canberra: $127-$ 13

Brown AG, 1997. Alluvial Geoarchaeology: Floodplain, archaeology and environmental change, Cambridge, Cambridge University Press: pp. 404

Chakrabarti C, Bhattacharyya B, Chakravarty P, Banerjee SN, Gangopadhyay K and Sengupta G, 2007. Preliminary observations on the Growth of Early Historic settlement of Chandraketugarh, West Bengal - A Geomorphological approach. Man and Environment 32(2): 47-60.

Datta A, 2000. Geographical location of Ancient Tamralipta Port in Journal of Bengal Art 5: 129-137.

Gangopadhyay K, 2006. Artefacts and Natural Site Formation of the Early Historic Sites in Rupnarayan-Hugli Estuary, West Bengal. In: Sengupta G and Chakraborty S, eds., Archaeology of Early Historic South Asia. Pragati Publications in collaboration with Centre for Archaeological Studies and Training, Eastern India: 99112.

Goodbread SL Jr and Kuehl SA, 1999. Holocene and Modern sediment budgets for the Ganges - Brahmaputra river system, evidence for high stand dispersal to floodplain, shelf, and deep-sea depocentres. Geology 27(6): $559-562, \quad$ DOI $10.1130 / 0091-$ 7613(1999)027<0559:HAMSBF>2.3.CO;2.

Hait AK, Das HK Ghosh S, Ray AK and Chanda S, 1996. Environmental variations in the late Quaternary sequence of Kolaghat, West Bengal, India. Current Science 70(12): 1089-1092.

Indian Archaeology - A Review (IAR) 1954-55; 1973-74. Archaeological Survey of India, New Delhi.

Krumbein WC, 1941. Measurement and geological significance of shape and roundness of sedimentary particles. Journal of sedimentary Petrology 11(2): 64-72, DOI 10.1306/D42690F3-2B26-11D7$8648000102 \mathrm{C} 1865 \mathrm{D}$

Murray AS and Wintle AG, 2000. Luminescence dating of quartz using an improved single-aliquot regenerative-dose protocol. Radiation Measurements 32(1): 57-73, DOI 10.1016/S1350-4487(99)00253$\mathrm{X}$.

Ramachandran TN, 1951. Tamluk (Tamralipti). Artibus Asiae 1(15): 226-239.

Rudra K, 2009. Dynamics of the Ganga in West Bengal, India (1764 2007): Implications for science-policy interaction Quaternary International 227(2): 161-169, DOI 10.1016/j.quaint.2009.10.043.

Sengupta G, 1995. Archaeology of Coastal Bengal. In: Salles JF and Ray HP, eds. Tradition and Archaeology. Manohar: 115-128.

Singh LP, Prakash B and Singhvi AK, 1998. Evolution of the lower Gangetic Plain landforms and soils in West Bengal. Catena 33(2): 75-104, DOI 10.1016/S0341-8162(98)00066-6.

Stanley DJ, Hait AK and Jorstad TF, 2000. Iron stained Quartz to distinguish Holocene Deltaic from Pleistocene alluvial deposits in small core samples. Journal of Coastal Research 16(2): 357-367.

Tony R, Leferve D and Vella C, 2009. Delta plain development and environmental changes in the Petite, Camargue, Rhone delta, France in the last 2000 years. Quaternary Research 71(3): 284294, DOI 10.1016/j.yqres.2008.10.007.

Umitsu M, 1993. Late Quaternary sedimentary environment and landform evolution in the Bengal Lowland. Sedimentary Geology 83(34): 177-186, DOI 10.1016/0037-0738(93)90011-S.

Waters M, 1993. Principles of Geoarchaeology: A North American Perspective, Arizona, University of Arizona Press: pp. 398 